\title{
TESTING ON MARKET EFFICIENCY OF THE CACAO COMMODITY FOR THE FUTURES MARKET IN JAKARTA FUTURE EXCHANGE
}

\author{
Ria Maulida")1, Lukytawati Anggraeni**), and Samsul Hidayat Pasaribu ${ }^{* *}$ \\ *) School of Business, Bogor Agricultural University \\ Pajajaran Road, Bogor 16151 \\ **) Departement of Economics, Faculty of Economics and Management, Bogor Agricuture Univesrsity \\ Agatis Road Wing 4 Level 5, Bogor Agricuture Univesrsity, Darmaga Bogor 16680
}

\begin{abstract}
The investigation of the efficient market validity hypothesis is a favorite topic in financial literature. However, there are still limited research on futures market commodity, especially the futures market in Indonesia. The objectives of this study were to analyze the development of cacao commodity futures market trading and determine its market efficiency. This study used value of trading volume, daily spot price and futures price of cacao commodity trading market from December 2011 to December 2016. Descriptive analysis showed that the development of cacao commodity futures trading market from value of trading volume of cacao commodity experienced fluctuating growth between $-126.050 \%$ and $39.480 \%$, and average growth of cacao by $-6.462 \%$. Augmented Dickey-Fuller (ADF) root test, Augmented Engle Granger (AEG) Error Correction Model Test (ECM) were used as the bases for the analyses. The results of the study showed that cocoa commodity futures market in Indonesia is an efficient market and contained risk premium. The implication of this research for market participants or investors is that they may choose to carry out hedging activities because cacao is an efficient market in the short term and contains risk premium.
\end{abstract}

Keywords: market efficiency, cacao commodity, value of trading volume, futures market, risk premium

\begin{abstract}
Abstrak: Penyelidikan keabsahan hipostesis market efisien merupakan salah satu topik favorit di bidang keuangan. Namun, masih sedikit yang melakukan penelitian mengenai pasar kontrak berjangka komoditi khususnya di pasar berjangka di Indonesia. Penelitian ini bertujuan untuk menganalisis perkembangan perdagangan pasar berjangka pada komoditi Kakao dan membuktikan adanya efisiensi pasar pada pasar berjangka komoditi Kakao di Bursa Berjangka Jakarta. Studi ini menggunakan nilai volume perdagangan, harga spot dan harga futures historis harian Kakao sejak bergabungnya komoditi Kakao di pasar berjangka pada bulan Desember 2011 sampai Desember 2016. Analisis deskriptif dilakukan untuk mengetahui perkembangan perdagangan pasar berjangka komoditi Kakao dilihat dari nilai volume trading Kakao mengalami pertumbuhan yang berluktuatif antara $-126.050 \%$ sampai $39.480 \%$, dan pertumbuhan rata-rata Kakao mencapai sebesar -6,462\%. Uji akar unit Augmented Dickey Fuller (ADF), Uji Augmented Engle Granger (AEG), dan Uji Correction Model (ECM) digunakan sebagai dasar menganalisis. Hasil dari penelitian ini menunjukkan bahwa pasar berjangka komoditi Kakao di Indonesia merupakan pasar yang efisien dan mengandung premi risiko. Implikasi dari penelitian ini bagi pelaku pasar atau investor dapat memilih melakukan aktivitas lindung nilai pada komoditi Kakao karena komoditi Kakao merupakan pasar efisien pada jangka pendek dan mengandung premi risiko
\end{abstract}

Kata kunci: efisiensi pasar, komoditi Kakao, nilai volume perdagangan, pasar berjangka, premi risiko

\footnotetext{
${ }^{1}$ Corresponding author:

Email: riamaulidar55mbipb@gmail.com
} 


\section{INTRODUCTION}

Commodity market is an organized trading place for commodities with certain rules to be followed by stakeholders. Presence of commodity market is expected to fulfill commodity needs from the industry. Also, it is formed to ensure commodity trading is an important factor of concern since it can affect cacao export price volatility. High-low of commodity price will then determine the amount of supply and demand of the commodity in futures market.

One of traded commodity with price fluctuation are on agricultural commodities such as cacao (Batu, 2010). Cacao are being produced on many country, making its price gaining global attention. Indonesia are the third largest cacao producer after Ivory Coast and Ghana. Based on this fact, Indonesia should be able to determine its own price, however Indonesia still rely to international price. International and Indonesian price of cacao could be seen on Figure 1.

Global price of cacao and cacao price in Indonesia have price fluctuation. Uncertainty of this commodity price resulting in certain risks which could make it difficult to stakeholders on determining price reference on transaction. Futures market are one form on risk management in form of hedge (Batu, 2010). Futures market are market that trade standardized options, financial contract of commodities. Indonesia Futures market in Indonesia has been establied on 1999, named Jakarta Future Exchange (JFX). Operated on 15 December 2000, JFX are currently trading cacao as one of its product as one of the most potential commodities to expand.
Indonesia has a fierce competition on cacao export due to low quality on cacao beans. Cacao bean in Indonesia still have high contamination had yet to be fermented, resulting on this low quality. This results in the fluctuation volume and value of cacao export from Indonesia. International trade also became an important factor of concern since it could affect cacao export price volatility. High-low of commodity price will then determining the amount of supply and demand of said commodities on futures market.

Even though the trading volume of cacao in future market still fluctuates, in recent years it has the tendency to increase. High demand in cacao creates a good investment opportunity; therefore, price movement of cacao becomes one factor that investors need to pay attention at.

Spot prices and future prices for cacao can be seen in Figure 1. Uncertainty in commodities price becomes the reason for the stakeholders to conduct hedging to avert the risk. Aside from averting risks, the stakeholder also try to seek capital gained either from spot prices or futures prices. This price movement could be used as benchmark of market efficiency. To measure efficiency level of a market, one method commonly used is called Efficient Market Hypothesis. This hypothesis was firstly proposed by Fama (1970) stating that efficient market is defined as a market where prices always reflect fully available information, and there is no way investors can gain abnormal returns. Efficient future market may signal effective spot prices so that investors and hedgers are able to utilize the information to obtain abnormal returns. Therefore, it is important to give further information to stakeholder regarding cacao future market.

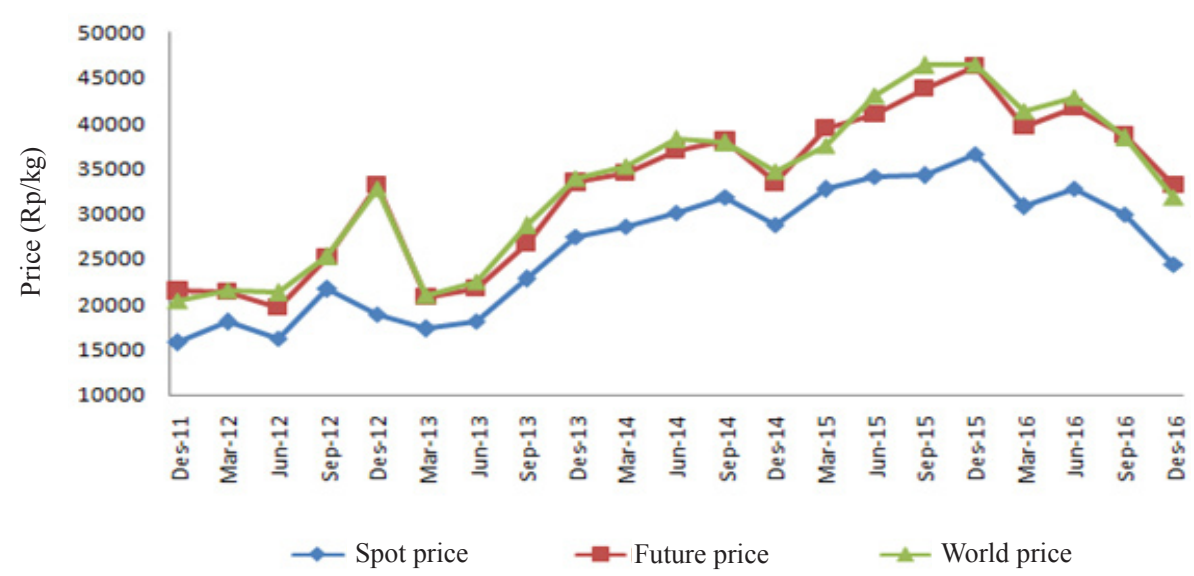

Figure. 1 Cacao price (World Bank, 2016; BAPPEBTI, 2016) 
Study on efficient market hypothesis validity becomes the most favorable topic on finance. However, there is still limited research studying future market as the object, especially Indonesia Future Market. Several studies on future market had been previously conducted such as the studies by Ali and Gupta (2011), Ranganathan and Kumar (2014), Kumar and Pandey (2013), Chakrabarty and Sarkar (2010), Phukubje and Mohalwa (2006), Malhotra and Sharma (2013), Neto and Garcia (2016), Ghimir et al. (2016), Zelda and Efe-Omojevwe (2013). Study on the market efficiency testing in Indonesia on Arabica, Robusta, and Olein had been conducted. Pertiwi (2015) and Dewi et al. (2011) tested the efficiency on Robusta, Arabica, and Olein in Jakarta Future Exchange. Meanwhile; however, efficiency study on cacao has not been carried out. According to the explanation above, the research questions for this study are as follows: 1) what is the current condition of cacao commodity in Jakarta Future Exchange. 2) Does cacao commodity in Jakarta Future Exchange have long-term efficiency? 3) Does Cacao commodity on Jakarta Future Exchange have short term efficiency? This research was limited in studying the historical trading volume, daily spot prices and future prices on the future market for the period of 2011-2016.

\section{METHODS}

This research used the secondary data collected from various sources, and the observation period of this study was from December 2011 to December 2016. Summary of data and sources used is shown in Table 1. This research observed the spot prices and future prices of cacao; therefore, the time series data were used.

Table 1. Data and Data Source

\begin{tabular}{ll}
\hline Data & Sources \\
\hline Cacao Trading Volume & JFX \\
Spot Prices and Future Prices & BAPPEBTI \\
Total production Kakao & www.bps.go.id \\
\hline
\end{tabular}

The descriptive statistical analysis provided a picture of data through total trading volume, trading volume value, lowest and highest trading values and average trading value to explain the data from the variables studied. Stationary test is an important test to be carried out in time series analysis to ensure that the result from the model is not spurious (Ariefanto, 2012). The stationary data were used by using Augmented DickeyFuller (ADF) as modelled below:

$$
\Delta \mathrm{S}_{\mathrm{t}}=\lambda \mathrm{o}+\lambda_{1 \mathrm{t}}+\mathrm{boS}_{\mathrm{t}-1}+\sum_{\mathrm{t}=1}^{\mathrm{k}} \mathrm{bi} \Delta \mathrm{S}_{\mathrm{t}-\mathrm{i}}+\mathrm{e}_{\mathrm{t}}
$$

Where: $\Delta \mathrm{St}=\mathrm{S}_{\mathrm{t}}-\mathrm{S}_{\mathrm{t}-1}, \mathrm{~S}_{\mathrm{t}}$ are spot price index in the future and $\mathrm{K}$ chosen as deviation white noise. Same relation are used to determin future price index; $\lambda_{0}$ (Constant (intercept)); $\lambda_{1 t}$ (Time frame); b0,b1(Estimated coefficient); $\mathrm{e}_{\mathrm{t}}$ (White noise).

The hypotheses on the stationary test are as follows: $\mathrm{H} 0-1: \mathrm{b} 0=0$, Unit root found, non-stationary Ha- $1: \mathrm{b} 0 \neq 0$, No unit root, stationary

\section{Cointegration Test Augmented Engle-Granger}

Kenourgios (2005) defines cointegration as a necessary condition for market efficiency. The first step is to construct model and test the error. Cointegration regression model is: $\mathrm{S}_{\mathrm{t}}=\beta_{0}+\beta_{1} \mathrm{~F}_{\mathrm{t}-1}+\varepsilon \mathrm{t}$

Cointegration test with estimated unbalanced error model: $\varepsilon_{\mathrm{t}}=\mathrm{S}_{\mathrm{t}}-\beta_{0}-\beta_{1} \mathrm{~F}_{\mathrm{t}-1}$ where: $\Delta \varepsilon_{\mathrm{t}}=\gamma \sum \varepsilon_{\mathrm{t}-1}+\theta \sum \Delta \varepsilon_{\mathrm{t}-1}$; $\mathrm{S}_{\mathrm{t}}$ (Spot price); $\mathrm{F}_{\mathrm{t}-1}$ (Future price $\mathrm{t}-1$ ); $\beta_{0}$ (Constant (intercept)); $\beta_{1} \quad$ (Estimated coefficient); $\varepsilon_{\mathrm{t}}$ (White noise).

If unbalanced residual error $\left(\varepsilon_{t}\right)$ is stationary, then it is concluded that there is cointegration between futures price and spot prices. Meanwhile, if the residual error is not stationary, then it is concluded that there is no cointegration between future price and spot price.

\section{Short Term Efficiency Test and Risk Premium: Error Correction Model (ECM)}

Market with long term equilibrium will have possibilities to have an unbalanced equilibrium in the short term. Correction to this short term of disequilibrium is carried out by using the error correction model. The ECM model is as follows:

$\Delta \mathrm{S}_{\mathrm{t}}=\alpha+\delta_{0} \mathrm{ECT}_{\mathrm{t}-1}+\delta_{1} \Delta \mathrm{F}_{\mathrm{t}-1}+\delta_{2} \mathrm{DV}_{\mathrm{t}}+\mathrm{u}_{\mathrm{t}}$

Where: $\mathrm{S}_{\mathrm{t}}$ (Spot price); $\delta_{\mathrm{t}}$ (Estimated coefficient); ECT (Error Correction Term); $\mathrm{F}_{\mathrm{t}-1}$ (Future price t-1); DV (Dummy Variable); DV (1 = Bountiful cacao harvest); DV $(0=$ Unbountiful cacao harvest $) ; u_{t}$ (white noise)

Hypothesis for Error Correction Model are as below:

H0 : Cacao future market are not efficient (Where $\alpha \neq 0$ and $\delta \neq 1)$ and $(\delta 1)$ 
Ha1: Cacao future market are efficient market and does not contain risk premium (where $\alpha=0$ and $\delta=1$ )

Ha2: Cacao future market are efficient market and containing risk premium (where $\alpha \neq 0$ and $\delta \neq 1$ ) and $(0<<1)$.

Based on the above description, the theoretical framework of this research is shown in Figure 2.

\section{RESULTS}

\section{Development of Cacao Future Market}

Cacao future market has had a significant improvement over the years especially in trading volume. Cacao commodity in Jakarta Future Exchange provides information to investors to invest in the commodity. Transactions on cacao contract are attracting investors in future market due to its significant improvement. Trading volume contract of cacao in future market can be seen in Table 2 .

The volume value of cacao future market had fluctuated growth between $-126.050 \%$ and $39.480 \%$. On average, growth of cacao future market was $-6.46 \%$ from 2011 to 2016. This was because the international price of cacao declined from Rp42,624/kg in 2015 to Rp38,311/kg in 2016. Meanwhile, in the previous years, there was no significant price increase on cacao.
Table 1 shows that in 2011, the volume value reached Rp173,990 million for an 11-trading day. This volume value was considered extremely high for a relatively new product listed on JFX. In 2012, cacao trading value increased again by $\mathrm{Rp} 5,541,011$ million for a 247-trading day. This was caused by price increases in cacao in Europe and America. Damayanti (2012) stated that cacao export in Indonesia was pushed by the increase on global demand. This issue was utilized by the investors to invest on cacao.

In 2013, the average volume of cacao increased by $8.084 \%$ from the previous year. This increase was considered small compared to that of the previous year. BAPPEBTI stated that cacao supply slightly declined in July 2013 and triggered increase on cacao import; as a result, there was a small increase on cacao volume in 2013. In 2014, cacao trading volume increased by $16.399 \%$ better than that of the previous year. The average volume reached Rp29,313 million per days. This increase was caused by increase in cacao futures price and depreciation on exchange rate.

During the observation period, cacao had its highest average increase in 2015 by $39,480 \%$. Average trading value reached Rp48.434 million per day. According to Bappebti (2015), this increase was caused by external factors such as increase in the number of the Indonesia middle class population interested in investing in cacao futures market. Monetary and exchange rate policy were also believed to be in investors' favor. Depreciation on exchange rate would give excessive return to investors on cacao futures market.

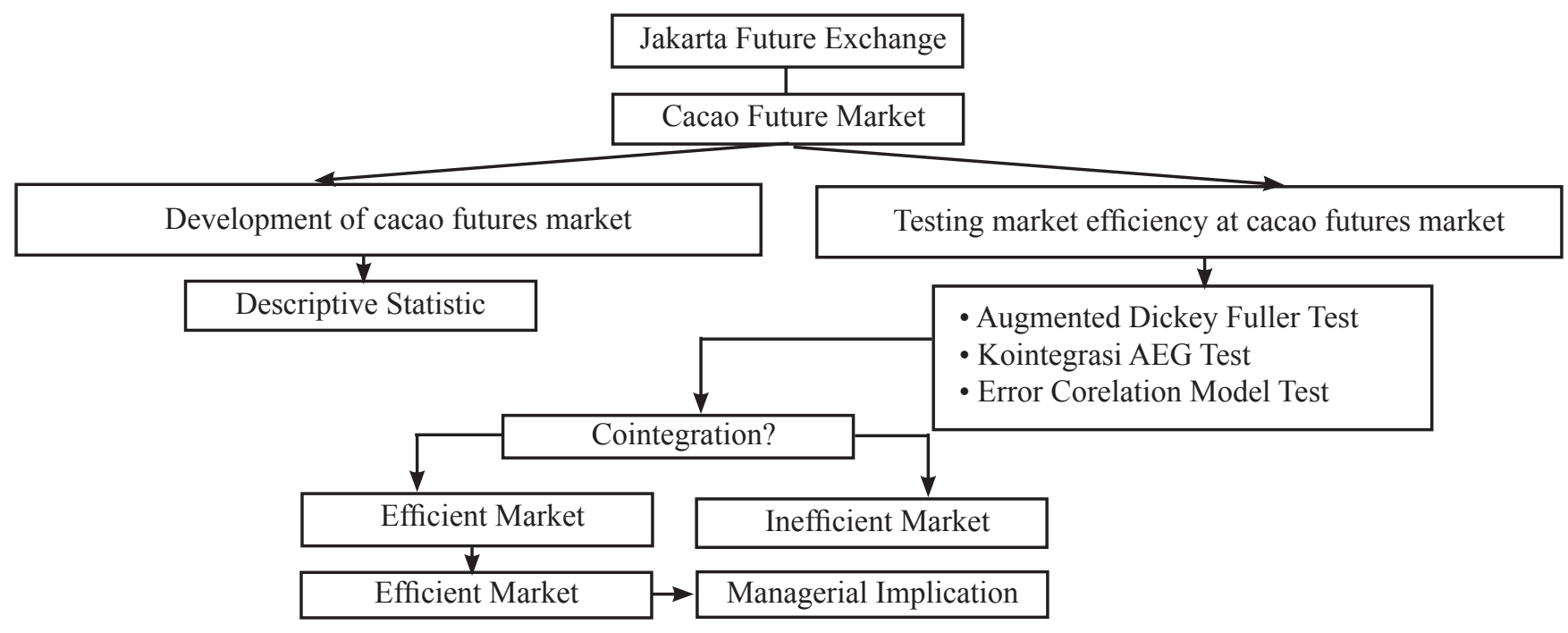

Figure 2. Research framework 
Table 2. Trading volume cacao future market

\begin{tabular}{lcccccc}
\hline \multicolumn{1}{c}{ Year } & 2011 & 2012 & 2013 & 2014 & 2015 & 2016 \\
\hline Days Traded & 11 & 247 & 244 & 241 & 229 & 241 \\
Total (Mil Rp) & 173.990 & 5.541 .011 & 5.979 .349 & 7.035 .004 & 11.043 .041 & 5.185 .187 \\
Min ( Mil Rp) & 1.439 & 3.055 & 16,765 & 524,073 & 157,971 & 749,846 \\
Max (Mil Rp) & 38.795 & 92.506 & 39.714 & 129.770 & 901.292 & 416.077 \\
Average (Mil Rp) & 15.817 & 22.524 & 24.506 & 29.313 & 48.434 & 21.426 \\
Average Growth (\%) & & 29,777 & 8,084 & 16,399 & 39,480 & $-126,050$ \\
\hline
\end{tabular}

However, in 2016 the average trading volume significantly fell down by $126,050 \%$, amounting up to Rp21.426 million. The main factor causing this fall was the declining cacao spot and futures prices. The decreases in prices were caused by the declines of cacao global prices. Indonesia cacao prices still refer to the international prices (Bappebti, 2015). According to European Cacao Association (ACE), the European cacao industry was on its lowest in 7 years. This information is considered bad by the investors since it potentially reduces their return. Thus, leading investors avoid themselves from investing in cacao.

\section{Cacao Market Efficiency Test}

Unit root test is the first step to analyze time series data. Before we conduct the cointegration analysis, we must first see whether the data are stationary or not. The result of the unit root test using Augmented DickeyFuller test can be seen in Table 3.

The result shown in Table 3 shows that on level, the spot price and future price had the probability value over $5 \%(0,05)$; therefore, it is concluded that there is unit root found on the level. At the first difference, the probability values for both price were 0.000 , under 0.05 ; therefore, spot price and futures price are stationary at the first difference.

\section{Augmented Engle Granger Long Term Efficiency Test}

Long term efficiency test are used by cointegration test. Since spot price and future price are stationary at first difference, then both price are cointegrated at first degree (d1), there for requirement for cointegrated regression have been fulfilled. Next requirement must be fulfilled are regression residual must be stationary. Result from cointegration regression model could be seen at Table 4
The result from the cointegration test in Table 4 shows that the futures price was significantly affecting the spot price with the probability of 0.000 lower that 0.05 $(5 \%)$. This can be interpreted that if the futures spot price is increased by $\mathrm{Rp} 1 / \mathrm{kg}$, the spot price is allegedly to be increased by $\mathrm{Rp} 1,244 / \mathrm{kg}$. Spot price is positively correlated to futures price; therefore, an increase in futures spot price will follow an increase in spot price. The residual stationary test was carried out using ADF test. The result of the residual stationary test can be seen in Table 5.

The result of the residual ADF in Table 5 shows that the residual value was stationary with the probability of 0.017 below critical level of $5 \%$. This shows that spot price is cointegrated to future price. This cointegration indicates that cacao futures market is efficient in the long run. Ali and Gupta (2015) stated that cointegration presence shows a long term equilibrium between spot price and futures price. This condition shows that cacao price on futures market already reflects all available information. This information includes historical price and rational information spread on the market which may affect market price. Mechanism on efficient market is that the constructed market price will not stray from the estimated equilibrium price. Equilibrium price will be formed when all investors have fully evaluated the impact form incoming information.

Table 3. ADF Stationary Test Result

\begin{tabular}{|c|c|c|}
\hline ADF Test & Spot Price & Futures Price \\
\hline & \multicolumn{2}{|c|}{ Probility } \\
\hline ADF Level & 0,429 & 0,193 \\
\hline ADF First Difference & 0,000 & 0,000 \\
\hline
\end{tabular}

Table 4. Spot price and future price regression model result

\begin{tabular}{lll}
\hline \multicolumn{1}{r}{ Variabel } & \multicolumn{1}{c}{ Coefficient } & \multicolumn{1}{c}{ Prob } \\
\hline C & $-8196,177$ & 0,000 \\
F_1 & 1,244 & 0,000 \\
\hline
\end{tabular}


Table 5. ADF residual stationary test

\begin{tabular}{lll}
\hline \multicolumn{3}{c}{ Uji Augmented Dickey Fuller } \\
\hline ADF Level & t-statistik & Probility \\
\cline { 2 - 3 } & $-2,371$ & 0,017 \\
\hline
\end{tabular}

Cointegration of efficient market was also studied by Ali and Gupta (2011), and Ranganathan and Anantakumar (2014) who found that agriculture commodities are efficient on the long run, since there is cointegration between futures price and spot prices.

Commodity market can become inefficient due to a number of factors such as the government policy and macro factors. The same issues were stated by Ali and Gupta (2011) and Bhar and Hamori (2006) stating that the government policy on minimum price intervention and no market guarantee through certain foundations may cause market inefficient. However, for the cacao commodity, the Indonesia government via BAPPEBTI created price discovery and guaranteed the price in cacao commodity market (Batu, 2010). This created cointegration between spot price and futures price in cacao commodity. The macroeconomic factor can affect commodity price; therefore, it cause the futures price fluctuated; therefore, creating cointegration between prices is nonexistent. The research by Elizabeth (2013) shows that macroeconomic factors such as real exchange rate and oil price have cointegration with spot price and futures price.

\section{Short Term Efficiency and Risk Premium : Error Correction Model Test}

When testing short term market efficiency, there are possibilities of disequilibrium. Testing on disequilibrium market and seeking for risk premium availability can be conducted using Error Correction Model. The Error Correction Model test result can be seen in Table 6 .

Table 6. ECM Model Estimation

\begin{tabular}{lll}
\hline Variabel & Coefficient & Prob \\
\hline $\mathrm{C}$ & 0,681 & 0,986 \\
$\mathrm{ECT}_{\mathrm{t}-1}$ & $-0,086$ & 0,000 \\
$\Delta \mathrm{F}_{\mathrm{t}-1}$ & 0,056 & 0,029 \\
$\mathrm{DV}_{\mathrm{t}}$ & 22,732 & 0,808 \\
\hline
\end{tabular}

ECM is considered valid if error correction term is significant. The error correction term had probability value of 0.000 under critical level of $5 \%$. This means that that error correction model is significant with coefficient value of 0.086 . This shows that short term equilibrium will be corrected to long term equilibrium, where $8.640 \%$ of the correction process was carried out on the first day and the rest of $91.360 \%$ would be carried out on the following days.

Independent variable Ft-1 had a probability value of 0.029 , under critical value of $5 \%$. This indicates that there are a short term relationship between spot price and futures price and risk premium. The magnitude of this effect was explained by the coefficient value of 0.056 . Therefore, it can be concluded that the third hypothesis (Ha2) is accepted, since it satisfies the criterion of $b$ value in between $0<b<1$. It indicates that if futures price increases by $\mathrm{Rp} 1 / \mathrm{Kg}$, then spot price will increase by $\mathrm{Rp} 0.056 / \mathrm{kg}$. This relationship occurred because it was conducted in a short term, and information obtained by the hedger regarding price movement can be compared with long term information. This information could be in the form of fundamental factors and macro economy factors. The results are in accordance to other commodities such as Arabica coffee and Robusta coffee. These commodities have an efficient market which contains risk premium (Prate, 2015), while other commodities are still inefficient (Dewi et al. 2011).

Risk premium is defined as hedger's compensation for every risk faced in transaction. The higher the risk on a market then the higher its risk premium becomes. Risks that can affect commodity market include global crisis and economic factor. Elizabeth (2013) stated that global crisis in 2008 had an impact on global oil price. The decline of global oil price caused spot and future prices of commodities to decline. Besides, other risks that should be paid attention at by investors include inflation risk, interest risk, exchange risk, regulation risk, and weather risk (Pertiwi, 2015). In 2016, depreciation of exchange rate also caused spot and futures prices of cacao to decline, reflected on its transactions. This was caused due to lower return obtained by the investors.

The dummy variable on this research included bountiful harvest. Bountiful harvest season will affect other commodities such as coffee, wheat, and corn. (BAPPEBTI, 2010). However, it is found that bountiful harvest season does not have a significant impact on spot price in cacao. The dummy variable had the probability value of 0.5483 higher than critical value of $5 \%$. Spot price of cacao is more likely be affected by supply and demand in market. 


\section{Managerial Implication}

Managerial implication from this result may be utilized by stakeholders in cacao futures market in terms of empirical information to assist investment decision making. The specific implications are as follows:

Investor

Investors and hedgers require analysis to predict price movement of cacao. Cacao commodity market is found to be efficient in long term and short term. In the long run investment, investors may utilize the historical futures price to predict current spot price. Information on this price movement could be used by investors as tools for investment decision making in cacao commodity. On the short term, cacao market is not only efficient but also contains risk premium, thus enabling investors to gain risk premium to obtain expected abnormal return.

\section{Farmers}

Farmers require market price of cacao in Indonesian market as price reference. Farmers may refer to cacao spot price in daily transaction. If cacao spot price tends to increase, they can also increase their price. On the contrary, when the price is low, they can put on hold their sales and wait for the price to increase.

\section{Government}

Indonesia as the third largest cacao exporter still relies on international price of cacao. This is a result of low quality and sub-standard cacao. BAPPEBTI as price referrer still uses international futures price as price reference, making it difficult for Indonesia to discover its own price. The government must act as regulator supporting the cacao commodity trade. The government regulation on cacao export quality will increase quality and price of cacao in international level, thus enabling Indonesia to discover its own price.

\section{CONCLUSIONS AND RECOMMENDATIONS}

\section{Conclusions}

Based on the data analysis and discussion above, the summary of this research is that cacao futures market had fluctuated growth from $126.05 \%$ to $39.48 \%$ with average growth of $-6.462 \%$ during the period of 2011-
2016. This was caused by the international cacao price experiencing a sharp fall in 2016. This led to negative growth of cacao transaction during that period. However, during 2011-2015, on average, growth of cacao trading volume increased significantly. Cacao futures market is proven to be an efficient long term market by the presence of cointegration between spot price and future price.The Error Correction Model (ECM) test showed a short term relationship between spot price and futures prices. Also, cacao futures market in Indonesia is found to be efficient and contains risk premium.

\section{Recommendations}

This study still has a great number of limitations on its own; therefore, it is suggested that for future research a study on efficient market hypothesis of integration test on other agricultural commodities should be conducted. Additional variable that may potentially affect cacao price such as macroeconomic variable can be added.

\section{REFERENCES}

Ali J, Gupta KB. 2011. Efiiciency in agricultural commodity futures markets in India. Journal Agricultural Finance 71(2):162-178. https://doi. org/10.1108/00021461111152555.

Ariefianto MD. 2012. Ekonometrika Esensi dan Aplikasi dengan Menggunakan Eviews. Jakarta: Erlangga.

Bappebti. 2015. Annual report.: https://www.bappebti. go.id. [3 Januari 2017].

Batu PL. 2010. Perdagangan Berjangka. Jakarta: PT Elex Media Komputindo Kompas Gramedia.

Bhar R, Hamori S. 2006. Linkages among agricultural commodity futures prices: some further evidence from Tokyo. Applied Economics Letters 13(8): 53-59. https://doi. org/10.1080/13504850500400421.

Chakrabarty R, Sarkar A. 2010. Efficiency of the Indian commodity and stock market with focus on some agriculture product. Paradigm 14(1). 85-96. https://doi.org/10.1177/0971890720100110.

Damayanti D. 2012. Indutri kakao. Office of Chief Economist Mandiri 11:1-4.

Dewi A, Siregra H, Manurung AH. 2011. Analisis kontrak berjangka olein di bursa berjangka Jakarta. Jurnal Manajemen dan Agribisnis 8(1):1-9.

Elizabeth N. 2013. Perilaku harga spot dan futures olein 
terkait variabel makroekonomi [tesis]. Bogor: Institut Pertanian Bogor.

Fama EF, Jensen MC, Roll R. 1969. The adjustment of stock prices to new information. International Economic Review 1(1):1-21. https://doi. org/10.2307/2525569.

Fama EF.1970. Efficient Market: A review of theory and emprical work. Journal of FinanceI 23(2): 383-417. https://doi.org/10.2307/2325486.

Ghimire B, Annussek K, Harvey J, Shamra S. 2016. Testing the weak form efficiency of agriculture's capital market. Economics and Business Review 2(2): 3-17. https://doi.org/10.18559/ ebr.2016.2.1.

Kenourgios DF. 2005. Testing efficiency and the unbiasedness hypothesis of the emerging greek futures market. European Review of Economics and Finance 4(2):3-20.

Kumar B, Pandey A. 2013. Market efficiency in Indian commodity futures markets. Journal of Indian Business Research 5(2):101-201. https://doi. org/10.1108/17554191311320773.

Malhotra M, Sharma DK. 2013. Efficiency of guar seed futures market in India: an empirical study. Journal of Applid Finance 19(2): 45-63.
Neto OJ, Garcia FG. 2013. The efficiency of the futures market for Brazilian live cattle. Academia Revista Latinoamericana de Administacion 26(2): 199-228. https://doi.org/10.1108/ARLA06-2013-0065.

Pertiwi D. 2015 Pengujian efisiensi pasar dan tingkat konvergensi harga komoditias Kopi arabika dan Kopi robusta. Jurnal Manajemen Pemasaran 9(2): 43-53.

Phukubje M P, Moholwa MB. 2006. Testing for weakform efficiency in South African futures markets for wheat and sunflower seeds. Agrekon 45(2): 198-213. https://doi.org/10.1080/03031853.200 6.9523743.

Ranganarhan T, Ananthakumar U. 2014. Market efficiency in Indian soybean futures market. International Journal of Emerging Market 9(4). 520-534. https://doi.org/10.1108/IJoEM-122011-0106.

Zelda, Efe-Omojevwe. 2013. A study of the efficiencies of maize and wheat futures market in India. Journal of Agriculture and Veterinary Science 2(4): 9-14. https://doi.org/10.9790/23800240914 . 